\title{
The Difference Between Certified and Non-certified PE Teachers Performance Based on Range of Service Period
}

\author{
Wahyo \\ Program of Postgraduate, \\ Universitas Negeri Medan \\ Medan, Indonesia \\ wahyoemedan@gmail.com
}

\author{
Albadi Sinulingga \\ Program of Postgraduate, \\ Universitas Negeri Medan \\ Medan, Indonesia
}

\author{
Nurhayati Simatupang \\ Program of Postgraduate, \\ Universitas Negeri Medan \\ Medan, Indonesia
}

\begin{abstract}
This research was conducted in junior high schools (SMP) in Deli Serdang Regency, North Sumatra Province. This research has been conducted for 2 months, namely October to November 2018. The population in this study were all physical education teachers who taught in the SMP throughout Deli Serdang District. The sample in this study were 12 physical education teachers who would be sampled to distribute the questionnaire. While the respondent representatives for the interview took 3 physical education teachers, 3 school principals, and 1 supervisor. This research is a mix methods research, which is a research step by combining two forms of approaches in research, namely qualitative and quantitative. The conclusions in this study are that classically the results of the percentage of teachers who were certified were $84.44 \%$ which was in the Very Good category. Based on data, the overall percentage for teachers who have not been certified $75.97 \%$ means that the performance of teachers who have not been certified is good.
\end{abstract}

Keywords- difference, teachers performance, certified, education

\section{INTRODUCTION}

Education is a conscious and planned effort to create a learning atmosphere and learning process for students to actively develop their potential to have religious spiritual strength, self-control, personality, intelligence, noble character, and skills needed by themselves and society. Education is a conscious and systematic effort to achieve a standard of living or for better progress. In simple terms, the notion of education is a learning process for students to be able to understand, understand, and make people more critical in thinking[1,2].

The main components that can affect the quality of education are: students, financing, management, and teachers. Teachers are professional educators who play a role in increasing intelligence, attitudes and behavior of students to become better human beings. Teachers can educate and shape the personality of students so that they have high intellectuality and responsible leadership. The teacher is also a person who provides knowledge to students. Teachers carry out education in certain places, not necessarily in formal educational institutions but can also be carried out in nonformal educational institutions such as mosques, mosque / prayer rooms, at home and so on. There is a tendency that FPOK / FIK (Faculty of Sports and Health Education / Faculty of Sport Sciences) in Indonesia is less sensitive and earnest in anticipating the dramatic development of the age demands that encourage all subjects in schools, including Penjas, to always be adapted to global developments in the world, As a result the Penjas program in schools has never gone far from just the process of "exercising children", with a goal that is not too far from the process of socializing the sports movement [3-5]

Judging from the results of the teacher's competency test, the competencies multiplied by motivation will affect performance [6]. This means that the higher the competency and motivation test the higher the performance. Based on the results of the teacher competency test conducted by the Ministry of Education, the data shows that the higher the teacher's working period, the lower their UKG score will be. This means that the older the teacher the lower the value of their UKG. And the younger the teacher's age, the higher their UKG score will be. This can be seen in the following table: 
Teachers' Score on 2015 UKG (20.972 PLPG Participants)

\begin{tabular}{|c|c|c|c|c|}
\hline $\begin{array}{c}\text { years of } \\
\text { service }\end{array}$ & total & average & $\begin{array}{c}\text { UKG } \\
\text { MAX }\end{array}$ & UKG MIN \\
\hline $10-14$ & 16891 & 58,40 & 79,76 & 4,46 \\
\hline $15-19$ & 2064 & 55,21 & 79,76 & 16,37 \\
\hline $20-24$ & 1261 & 50,79 & 78,87 & 20,24 \\
\hline $30-29$ & 630 & 50,01 & 79,76 & 22,32 \\
\hline $35-39$ & 3 & 48,08 & 78,87 & 19,05 \\
\hline
\end{tabular}

Source: Muchlas's explanation of the 2015 UKG teacher data on UKG results

Discussing teacher performance is very interesting because the teacher is a determining factor to produce students who master the mindset (intellectual intelligence) is high, educational models can do forms of teaching in the context of the transfer of knowledge. Meanwhile, efforts to produce students have a realm of sense (social intelligence), a realm (mental intelligence / psychology), and a religious realm (spiritual intelligence) is high, the educational model must be developed through exemplary (exemplary), keploporan and habituation order of transfer of value or civilization of values of national character. Whereas efforts to produce students who have a body (kinesthetic intelligence) are high, then education can be done through a model of practice and habituation in order to develop reflexes and dexterity in action [7-10].

The task of the teacher as a profession, requires the teacher to develop professionalism according to the development of science and technology. Educating, teaching, and training students is the duty of the teacher as a profession. The task of the teacher as an educator, to continue and develop the values of life to students. The task of the teacher as a teacher means to continue and develop science and technology to students. The task of the teacher as a coach means developing skills and applying them to life for the sake of the future of students. Teachers must have the ability, expertise or often referred to as teacher competence[11-15]. There are four competencies that must be possessed by a teacher, namely competence: pedagogic, personality, professional and social.

The four competencies as teachers are managed through the process of teacher certification, with the title as a professional teacher. Certification is the process of giving certificates to teachers who have met the standards of teacher professionalism. Certification aims to improve teacher professionalism and welfare. Certification is carried out in the form of portfolio appraisal, assessment includes; a) pedagogical competence, b) professional competence, c) personality competency, and d) social competence. Portfolios are a collection of teacher personal information. Information in the form of notes and documentation of achievement of teacher's achievements in the field of education.

Based on the results of temporary observations in detail the researchers told several penjas teachers, Principals and Supervisors of SMP in Deli Serdang District with interview points on performance appraisal, among others: learning tools owned, communication with fellow teachers, parents of students and students, collaboration, exemplary technology utilization in KBM and assessment, the development of the potential possessed by the teacher shows the performance of physical education teachers in January 2018 Deli Serdang district junior high school teachers obtained the results that teaching is still releasing obligations, not arriving on time, teaching and learning tools (RPP, KKM, learning media) not equipped, then data from the school supervisor if seen in general there is no difference in the performance of teachers who have received certification allowances with the performance of teachers who have not received certification allowances in Physical Education subjects. From the explanation above, there are several problems that have to be solved, because according to the prevailing theory that compensation will affect performance [16].

Based on the above facts, the researcher compiled in the form of research with reference to "The Differences in the Performance of Certified Physical Education Teachers and Those Who Have Not Certified From the Difference of Working Period".

\section{DISCUSSION}

\section{A. Performance}

The term performance is a translation of English, work performance or job performance, but in English it is often abbreviated as Performance. Performance in Indonesian is also called work performance. Performance or work performance (performance) is interpreted as an expression of ability based on knowledge, attitudes, skills, and motivation in producing something. The word "performance" gives three meanings, namely: (a) "achievement" as in the context or sentence "high performance car", or "very fast car": (b) "show" as in the context or sentence "Folk dance performance" , or "Folk dance performances"; (c) "implementation of duties" such as in the context or the phrase "In performing his / her duties" [17].

According Simanjuntak [18] Performance is the level of achievement of results for the implementation of certain tasks in order to achieve organizational goals. In this case, Simanjuntak emphasized that performance is something important in order to achieve organizational goals, because each individual or organization in achieving that target or target is performance.

Prawirosentono [19] defines performance as the work that can be achieved by a person or group of people in an organization, in accordance with the authority and responsibility of each in order to achieve the objectives of the organization in question legally, not violating the law and in accordance with morals and ethics. Performance is an activity carried out to carry out, complete tasks and responsibilities in accordance with the expectations and objectives that have been set. Judging from the meaning of performance comes from the word Performance.

Based on the opinions above, performance is interpreted as an achievement, showing an activity or action and carrying out a task that has been charged for a certain period [20]. 
Performance is more often referred to as achievement, which is 'outcome' or 'what comes out' (outcomes) of a job and the contribution of human resources to the organization. In a company, according to Mutis, performance problems that can be identified from several angles include: (a) companies must be able to produce goods or services with increasing quality; (b) service to consumers is faster and more efficient; (c) suppressing production costs so that the cost of goods sold can be stable so that it can be felt by all consumers; and (d) increasing the knowledge and skills of workers so that they can innovate in meeting the needs of consumers who are always changing to adjust to the dynamics and demands of the times [21].

Performance contains the meaning of work, ability, achievement or encouragement to carry out a job. The success of individuals or organizations in achieving these targets or targets is performance. "Performance is the result of one's work in a certain period compared to several possibilities, for example the standard targets, targets, or criteria that have been determined in advance" [22].

Based on the opinions above it can be concluded that performance is the result of work that has been achieved by someone in an organization to achieve goals based on standardization or size and time adjusted to the type of work and in accordance with the norms and ethics that have been determined.

\section{B. Factors Affecting Performance}

Performance can be influenced by several things, including: motivation, competence, compensation, organizational climate, supervision, leadership, organizational culture and commitment. Husanker states that: "performance = motivation $\mathrm{X}$ ability. Ability $=$ aptitude $\mathrm{X}$ training $\mathrm{X}$ resources. Motivation $=$ desire $\mathrm{X}$ commitment "Thus, Performance $=$ aptitude $\mathrm{X}$ training $\mathrm{X}$ resources $\mathrm{X}$ desire $\mathrm{X}$ commitment. In this study the training intended in the study was in the form of supervision services provided by the principal, the resources were the atmosphere of the work climate, and the commitment contained in the effort to truly understand the curriculum [23].

Many factors that affect the quality of one's performance include: "(a) HR participation, (b) career development, (c) communication, occupational health and safety, (d) conflict resolution, (e) good incentives, and (f) pride "[24]. Other aspects that can be used to assess performance or work performance include: (a) ability to work, (b) craft, (c) discipline, (d) work relations, (e) initiative, (f) leadership or things specifically in accordance with the field and level of work he occupies

Another opinion regarding performance states: "Performance is a function of the interaction between abilities (basic abilities) with morivation (motivation), namely performance (performance) $\mathrm{P}=(\mathrm{AxM})$ " [25-29]. The theory shows that people who have low motivation will produce low performance as well as people who actually have high motivation, but low basic abilities, then their performance is also low. Someone with high performance besides having high basic abilities must also have high motivation. Motivation can be interpreted as an effort that raises the urge to do a task. The important concept of the above theory is that to uncover and measure teacher performance can be done by examining the teacher's basic abilities or the implementation of the teacher's basic competencies or his motivation in work.

\section{Teacher's profession}

Teacher's profession is a special field of work carried out based on the principle of: (a) having talent, interest, soul calling and idealism; (b) having a commitment to improve the quality of education, faith, piety and noble values; (c) having appropriate competencies needed in accordance with the field of duty; (d) obtain income that is determined according to work performance; (e) have the opportunity to develop professionalism on an ongoing basis; (f) has a guarantee of legal protection in carrying out professional duties; $(\mathrm{g})$ has a professional organization that has the authority to regulate matters relating to teacher professionalism.

Furthermore it is stated that: "Teachers must have academic qualifications, competencies, educator certificates, physical and spiritual health, and have competence to realize national education goals" [30].

\section{Definition of Teacher Performance}

Teacher performance is the appearance of the teacher's work which includes all quantitative and qualitative work displays. The performance criteria of teachers who can achieve their work performance are more directed at teacher competition as stated in Government Regulation No. 19 of 2005 concerning National Education Standards, that teacher performance, in this case teacher competence includes four competencies, namely: pedagogic competence, personality competence, professional competence, and social competence.

First, pedagogic competence, is the ability in the management of students, which includes:

1) Understanding of insight or educational foundation.

2) Understanding of students

3) Development of curriculum / syllabus

4) Learning design

5) Implementation of educational and dialogical learning

6) Evaluation of learning outcomes

7) Development of students to actualize their various potentials.

Second, personality competence, is a personality ability that includes:
a. Steady
b. Stable
c. Adult
d. wise and prudent
e. Authoritative
f. Noble character
g. Be an example for students and society
h. Evaluate your own performance
i. Develop yourself continuously 
The three professional competencies are broad and profound mastery of learning material, which includes:

a. Concepts, structures and methods of science / technology / art that overshadow teaching materials

b. Teaching materials available in the school curriculum

c. Conceptual relationships between related subjects

d. Application of scientific concepts in everyday life

e. Professional competence in a global context while preserving national values and culture.

Fourth, social competence, namely the ability of educators as part of the community to play a role in matters of rights:

a. Communicate oral and written

b. Use technology and information functionally

c. Associate effectively with students, fellow educators, educational staff, parents of students

d. Hang out politely with the surrounding community

A teacher is considered to have a good performance if he has the four competencies mentioned above, so that being able to carry out his duties as an educator in accordance with what is demanded by the organization in this case is school. And, in carrying out their role as educators, the quality of their performance is an important contribution that will determine the success of the education process at school. Therefore, attention to teacher performance to continue to increase and be increased becomes very important, especially when paying attention to the ever increasing demands of the community regarding the quality of education, and of course this will have implications for the increasing need for improving the quality of teacher performance.

\section{III.Conclusions and Recommendations}

\section{A. Conclusion}

Based on the data the percentage of physical education teachers in junior high schools in Deli Serdang District has been certified in the excellent category $(84.44 \%)$ and noncertification in the good category $(75.97 \%)$, but there are still obstacles namely the concept of learning in the dominant material taught is soccer. The problem of professional competence of physical education teachers who have been certified has not updated about the latest information and the use of technology is still lacking so that it influences the making of Learning Implementation Plans in evaluating and developing students' self-actualization

\section{B. Suggestion}

1. For physical education teachers, it is expected that they can work with a sense of responsibility and jointly apply a good and positive school culture with school citizens to create high quality education.

2. The high and low quality of education is a shared responsibility as citizens of the School by maintaining a close relationship between fellow School citizens and increasing their respective professionalism.

\section{REFERENCES}

[1] Ruky, A. S., Sistem Manajemen Kinerja, 2004, 2, 77-78.

[2] Bloom, B. S., Pembinaan untuk Peningkatan Kinerja Karyawan, 1981, 8, 29-30.

[3] Bucher., Epistemologi Ilmu Keolahragaan, 1997, 12, 211-212.

[4] Timpe, D., Kinerja, 1992, 3, 164-165.

[5] Pangrazi, D., Belajar dan Pembelajaran, 1989, 23, 89.

[6] Dessler, G., Human Resource Management, 2003, 7, 191-192.

[7] Gibson., Organisasi, 2008, 34, 76-77.

[8] Hikmad., Kinerja Guru SD Sekabupaten Pinrang, 2012, 57(2), 233-234.

[9] Kopelman, R. E., Manajemen Produktivitas Total Strategi Peningkatan Produktivitas Bisnis Global, 1986, 11, 98-99.

[10] Latham., Kebijaksanaan Kinerja Pegawai, 1990, 32, 193-194.

[11] Mahendra., Pendidikan Olahraga, 2004, 12(2), 19-20.

[12] Yamin, M., Sertifikasi Profesi Keguruan di Indonesia, 6, 176-177.

[13] Muslich, M., Sertifikasi Guru Menuju Profesionalisme Pendidik, 2007, 71, 179-180.

[14] Morgan., Kinerja Guru, 2012, 23, 96-97.

[15] Mulyasa, E., Standar Kompetensi dan Sertifikasi Guru, 2008, 13, 89.

[16] Nanawi., Kompetensi Guru, 2011, 32, 201-202.

[17] Nixon., Pendidikan Jasmani Olahraga, 1963, 14, 300-301.

[18] Simanjuntak, P. J., Manajemen dan Evaluasi Kinerja, 2005, 7(4), 145 146.

[19] Prawirosentono, S., System Analysis Design \& Implementasi, 21, 189 190.

[20] Samani., Sertifikasi Guru, 2007, 9, 123-124.

[21] Slavin, R. E., Cooperative Learning, 1990, 207-208.

[22] Soeprihanto, J., Penilaian Kinerja dan Pengembangan Karyawan, 1996, 10, 112-113.

[23] Sri., Hubungan Kompetensi dengan Kinerja Guru SD Negeri Palangkaraya, 2013, 95-96.

[24] Robbins, S. P., Teori Organisasi Struktur Design dan Aplikasi, 1994, 3 , 164-165.

[25] Suma'mur., Hiegiene Perusahaan dan Keselamatan Kerja, 2009, 7, 119 120.

[26] Surya., Prestasi Belajar dan Kompetensi Guru, 2000, 27, 117-118.

[27] Tiffin, J., Manajemen Kinerja, 2000, 13, 114.

[28] Thoby, M., Kewirausahaan yang Berproses, 1995, 20, 174-175.

[29] Uzer, U., Menjadi Guru Profesional, 1995, 11, 321-322.

[30] Ministry of Education (2008). Instrumen Penilaian PLPG 